\title{
Renin - angiotensin system (RAS) and hypertensive disease "From the link in pathophysiology to the outcomes of inhibition"
}

\author{
Asim M. Al-Chalabi
}

Consultant Physician, Ninaveh Private Hospital.

(Ann. Coll. Med. Mosul 2009; 35(1): 73-86).

Received: 15 ${ }^{\text {th }}$ Nov 2009; Accepted: $2^{\text {nd }}$ Dec 2009.

\section{SUMMARY}

The renin - angiotensin system is a major contributor to both hypertension and associated pathophysiologic changes in the heart and cardiovascular wall (The target organ). Major basic and clinical trials have shown that ACE inhibitor and ARB are the main renin- angiotensin system blockers in use assist in controlling hypertension and reducing target organ damage, thus they should be used as a first-line treatment for hypertension. Moreover, ARBs specifically reduces the frequency of atrial fibrillation and stroke, thus it has emerged as a new preventive and therapeutic strategy for these conditions.

In theory, combining ACE inhibitor and ARBs maximizes benefits because it offers more complete RAS blockage but this expectation was not confirmed by most recent clinical trials and was not translated into real patients benefits. Renin inhibition was introduced as a better step for reducing angiotensin II, because it offer complete blockage of the whole system. Early studies confirmed that renin inhibitors reduced blood pressure better than ACE inhibitors but further large clinical trials have been started and therefore in the near future, further clinical evidences will be available to confirm the antihypertensive, anti-inflammatory and antiatherosclerotic effects of renin inhibitor.

List of abbreviations: RAS (renin - angiotensin system), ACE (angiotensin converting enzyme), ARB (angiotensin receptor blocker), $\mathrm{AT}_{1}$ (angiotensin II receptor type 1), $\mathrm{AT}_{2}$ (angiotensin II receptor type 2), $\mathrm{AT}_{4}$ (angiotensin II receptor type 4), LVH (Left ventricular hypertrophy), AF (atrial fibrillation), CCF (Congestive heart failure).

نظام الرنين انجيوتتسين هو عامل رئيس لكل من فرط ضغط الدم و التغيرات المرضية في القلب وجدار الأوعية الدموية

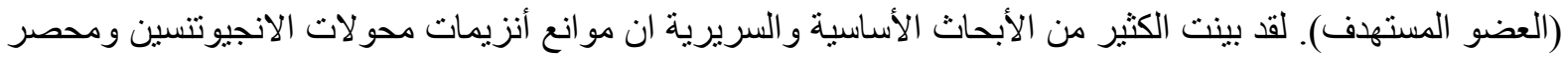

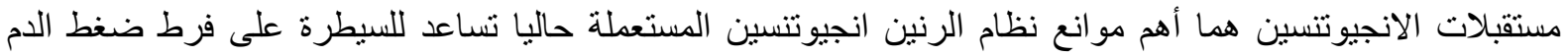

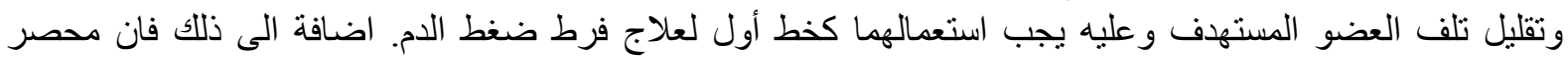

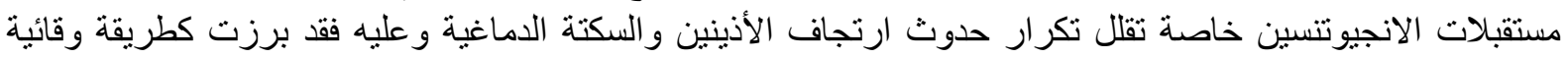
و علاجية جديدة لهذه الأمر اض.

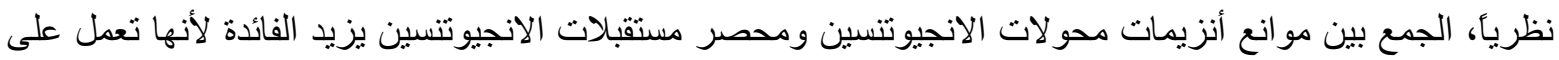

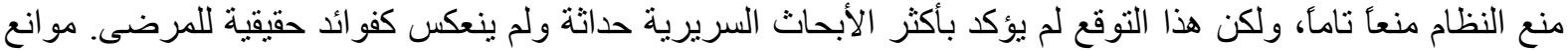

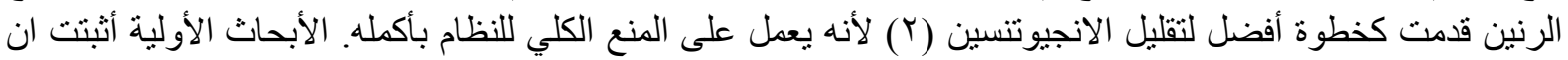

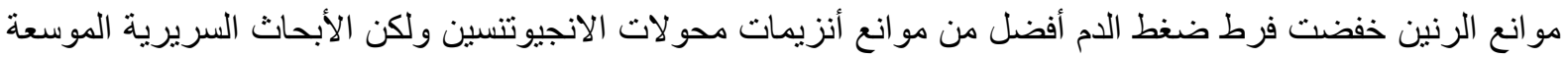

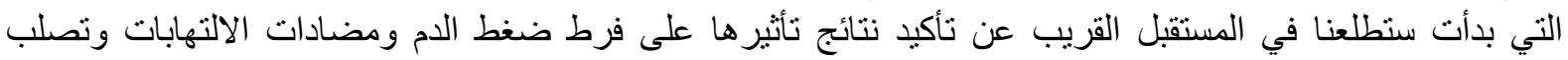


A direct, continuous and independent relation between blood pressure and the incidence of various cardiovascular events, such as stroke and myocardial infarction is well accepted. This increase in risk can be attributed to structural and functional changes in target organs. Central to many of these pathophysiologic process is the renin angiotensin system "RAS" specifically angiotensin II. In fact, the RAS is a major regulatory system of cardiovascular and renal function, and is a major contributor to both hypertension and associated pathophysiologic changes in the heart and vascular wall. Accordingly, the renin - angiotensin system has been at the center of intensive research activities for several decades.

Accordingly, in the last twenty years, growing evidence has clearly pointed out that RAS activity may represent an ideal target for pharmaceutical treatment in a number of cardiovascular diseases, including hypertension, atherosclerosis, congestive heart failure, renal diseases, stroke, myocardial infarction and others. In fact, evidences provided by major clinical trials and the continuously increasing use of ACE inhibitors in the clinical practice as well as of RABs has confirmed the value of inhibiting the RAS as an effective approach to reduce cardiovascular risk and cardiovascular and renal complications associated with major diseases ${ }^{(1)}$.

Thus, blockade of RAS is now evidence based strategy for the protection of cardiovascular, cerebrovascular and renal systems. This article reviews the current views on the biophysiology of RAS, its link to pathophysiology of hypertensive disease, and discuss the outcomes of its inhibition in this condition.

\section{Biophysiology of RAS}

The RAS comprises a cascade of enzymatic reactions resulting in the formation of Angiotensin II, which is the effective molecule of the RAS and can act as a systemic hormone "Endocrine" or as a locally generated factor "paracrine". Figure $1^{(2,3)}$. Renin is a proteolytic enzyme that is produced and stored in the granules of the juxtaglumerular cells surrounding the afferent arterioles of the glomeruli in the kidney. Renin acts on the basic substrate angiotensinogen (a circulating $\alpha 2$-globulin made in the liver) to form the decapeptide angiotensin । (figure1). Angiotensin $\quad I$ is then enzymatically transformed by angiotensin converting enzyme "ACE", which is present in many tissues particularly pulmonary vascular endothelium, to the octapeptide angiotensin II by removing of the two c-terminal amino acids.

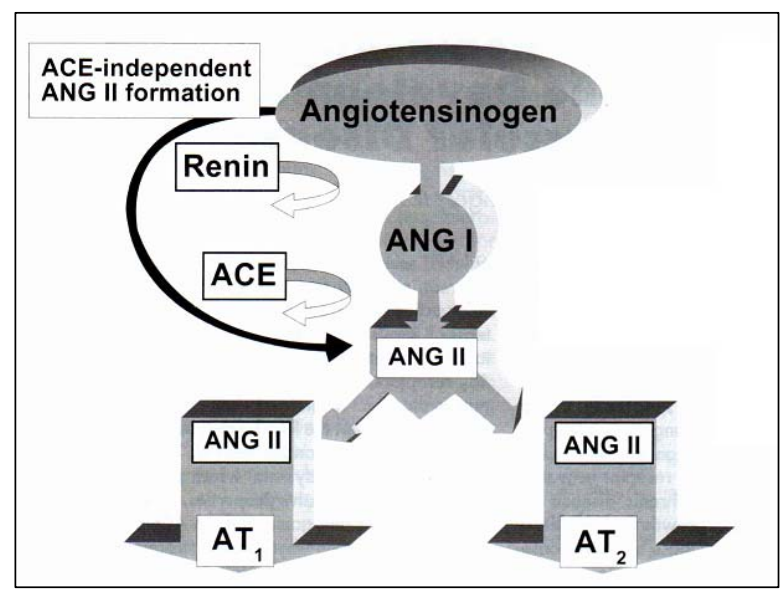

Figure (1): Simplified overview of RAS pathway. Reproduced with permission from Prof. T. Unger, the role of the reninangiotensin system in the development of cardiovascular disease. AMJ card. ${ }^{(31)}$.

Regardless of the pathway by which it is formed, angiotensin II is a potent pressor agent and mediate its physiologic effects by a final common step: binding to highly specific receptors located on the cell membrane. In humans two main types of angiotensin II receptor subtypes have been characterized: angiotensin II type $1\left(\mathrm{AT}_{1}\right)$ and angiotensin II type $2\left(\mathrm{AT}_{2}\right)$ which differ markedly in their biological activities ${ }^{(4,5)}$.

\section{The angiotensin type -1 receptor $\left(A T_{1}\right)$}

The $\mathrm{AT}_{1}$ receptor is a 7 -transmembrane domain receptor, coupled to a guanosine triphosphate - binding protein "G-protein". It is located primarily in the adrenal glands, vascular smooth muscle cells, kidney, and heart ${ }^{(4)}$. 
Virtually all of the known regulatory actions of angiotensin II on blood pressure and osmoregulation have been attributed to $\mathrm{AT}_{1}$ receptor. These include vasoconstriction, aldosterone and vasopressin release, renal tubular sodium reabsorption, and decreased renal blood flow (table 1). Although these effects on blood pressure and electrolytes homeostasis played an essential physiologic role at an earlier point in human evolution to maintain adequate organ perfusion at times of acute volume loss, they are now largely redundant in modern civilization. More important are the pathophysiologic consequences arising from $\mathrm{AT}_{1}$ receptor activation.

Table (1): Differential effects mediated by $A T_{1}$ and $A T_{2}$ receptors.

\begin{tabular}{|lc|}
\hline AT $_{1}$ receptor & AT $_{2}$ receptor \\
\hline - Vasoconstriction & \\
- Aldosterone synthesis and & - Fetal tissue \\
secretion & development \\
- Renal tabular sodium & - Inhibition of cell \\
reabsorption & growth/proliferation \\
- Increased vasopressin secretion & - Vasodilation \\
- Decreased renal blood flow & - Modulation of \\
- Renal renin inhibition & extracellular matrix \\
- Cardiac hypertrophy & - (Neuronal) \\
- Cardiac contractility & regeneration \\
- Vascular smooth muscle cell & - Cell differentiation \\
proliferation & - Apoptosis \\
- Augmentation of peripheral & \\
noradrenergic activity & \\
- Modulation of central & \\
$\quad$ sympathetic nervous system & \\
activity & \\
- Central osmocontrol & \\
- Extracellular matrix formation &
\end{tabular}

Reproduced with permission from Prof. T. Unger, the role of the renin-angiotensin system in the development of cardiovascular disease. AMJ card. ${ }^{(31)}$.

In this regard $A T_{1}$, receptor stimulation has been shown to mediate cell growth and proliferation of vascular smooth muscle cells ${ }^{(6)}$ cardiomyocytes ${ }^{(7)}$, and coronary endothelial cells ${ }^{(8,9)}$. Accordingly, the $\mathrm{AT}_{1}$ receptor has been implicated in various cardiovascular, renal and cerebral pathologies, such as left ventricular hypertrophy, vascular media hypotrophy, cardiac arrhythmias, atherosclerosis, glomerulosclerosis, stroke and dementia ${ }^{(9,10)}$. Inhibition of these effects by specific $A T_{1}$ receptor blockade can be expected to offer therapeutic benefit in certain pathologic condition e.g. hypertension, to inhibit vasoconstriction and prevent vascular and cardiac hypertrophy.

\section{The angiotensin type -2 receptor $\left(A T_{2}\right)$}

The $\mathrm{AT}_{2}$ receptor is also a 7-transmembrane glycoprotein and has approximately 34\% amino acid sequence homology to that of the $\mathrm{AT}_{1}$ receptor. Less is known about its signaling pathways. They are present at a high density in all tissues during fetal development, but they are much less abundant in adult tissue, being expressed at high concentration only in the adrenal medulla uterus, ovary, vascular endothelial and specific areas of brain (11). Expression is also upregulated under certain condition, such as in heart failure, post infarction repair, and skin and nervous system lesions ${ }^{(12,13)}$.

$A T_{2}$ receptors thus appear to be involved in the control of cell proliferation, cell differentiation and development, angiogenesis, wound healing, tissue regeneration, and even apoptosis (table 1), namely, biologic processes that counteract the trophic responses mediated through $A T_{1}$ receptors i.e. $A T_{2}$ receptor opposes $A T_{1}$ receptor - mediated effects ${ }^{(14-15)}$.

Speculation suggests that, in a milieu of selective $A T_{1}$ receptor blockade, circulating angiotensin II would act only at unopposed $\mathrm{AT}_{2}$ receptors, thereby amplifying the vasodilator component of the biphasic arterial blood pressure response to angiotensin II. By the same inference, $\mathrm{AT}_{1}$ receptor blockade would be expected to preserve "or even augment" the favorable effects of angiotensin II on cell growth and proliferation mediated through the $\mathrm{AT}_{2}$ receptor.

\section{Other enzymes and receptors}

In 2000, a new enzyme associated with the generation of angiotensin peptides was identified ACE2, a carboxy peptidase similar to ACE ${ }^{(16)}$. ACE2 does not generate angiotensin II but increases the formation of angiotensin (1-7) (figure 2). This heptapeptide causes vasodilatation and growth inhibition ${ }^{(17)}$ but 
ACE2 has several function that are not yet fully understood $^{(18,19)}$.

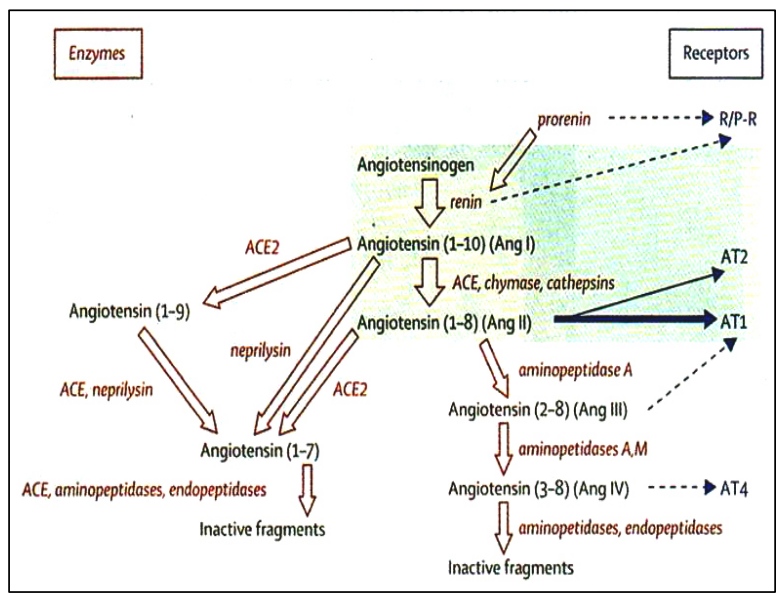

The effects of all angiotensin peptides are mediated through specific cell surface receptors (table 2). $A T_{1} \& A T_{2}$ already has been mentioned. An $\mathrm{AT}_{4}$ receptor for angiotensin IV was found recently to affects kidney tubular function and improves the memory of Rodents ${ }^{(20)}$. A renin - prorenin receptor was described by Nguyen and colleagues in $2002^{{ }^{(21)}}$. Work in animals support notion that over expression of the renin - prorenin receptor increase blood pressure ${ }^{(22)}$, but the role of this receptor in human beings remain to be established ${ }^{(23)}$, but might of particular importance for the effects of renin inhibitors.

Figure (2): Expanded overview of RAS pathway. Reproduced with permission from Prof. R. F. Schmieder. Renin-angiotensin system and cardiovascular risk. Lancet $2007^{(65)}$.

Table (2): Cell surface receptors of the RAS.

\begin{tabular}{|c|c|c|c|}
\hline & Full name & Ligand(s) & Function \\
\hline $\mathrm{AT}_{1}$ & Angiotensin II type 1 receptor & $\begin{array}{l}\text { Angiotensin II, } \\
\text { Angiotensin III }\end{array}$ & $\begin{array}{l}\text { Vasoconstriction, stimulation of aldosterone release } \\
\text { and sympathetic nerve activity, promotion of cell } \\
\text { growth, matrix deposition, inflammation }\end{array}$ \\
\hline $\mathrm{AT}_{2}$ & Angiotensin II type 2 receptor & Angiotensin II & $\begin{array}{l}\text { Antagonism of the effects of } \mathrm{AT}_{1} \text {, promotion of } \\
\text { apoptosis, protection of neural tissue, possible } \\
\text { synergism with } \mathrm{AT}_{1} \text { in promoting inflammation }\end{array}$ \\
\hline $\mathrm{AT}_{4}$ & Angiotensin IV receptor & $\begin{array}{l}\text { Angiotensin IV, } \\
\text { LVV-haemorphin } 7\end{array}$ & $\begin{array}{l}\text { Vasodilatation, decrease tubular sodium transport, } \\
\text { improved memory, possibly promoting inflammation }\end{array}$ \\
\hline $\mathrm{R} / \mathrm{P}-\mathrm{R}$ & Renin/prorenin receptor & Renin and prorenin & $\begin{array}{l}\text { Increase of angiotensin generation, further } \\
\text { independent promotion of matrix deposition }\end{array}$ \\
\hline mas & mas oncogene & Angiotensin (1-7) & $\begin{array}{l}\text { Antagonism of the effects of } A T_{1} \text {, antidivretic, inhibits } \\
\text { cell growth. Not yet clear whether or not all actions } \\
\text { of angiotensin (1-7) are mediated by mas oncogene }\end{array}$ \\
\hline
\end{tabular}

Reproduced with permission from Prof. R. F. Schmieder. Renin - angiotensin system and cardiovascular risk. Lancet $2007^{(65)}$.

\section{Angiotensin II and atherosclerosis}

At the beginning of the nineties, Dzau and Braunwald proposed the concept of the cardiovascular continuum in humans (figure 3 ) ${ }^{(24)}$. Accordingly, the onset and progression of cardiovascular disease can be regarded as a continuum of events, according to this concept, the presence of risk factors, such as hypertension, dyslipidemia, or diabetes mellitus and smoking, initially predisposes to the development of endothelial disfunction, atherosclerosis and target organ damage. 
Progression to overt coronary artery disease can cause clinical syndrome of myocardial ischaemia, whereas thrombus formation at the sites of an atherosclerotic plaque may occlude a coronary artery and results in myocardial infarction. Sequelae of myocardial infarction include cardiac arrhythmias and loss of cardiac muscle, potentially culminating in sudden death. However, if the individual survives the acute event, post infraction remodeling will occur, leading to ventricular dilatation, heart failure, and ultimately, end-stage heart disease, and eventually death.

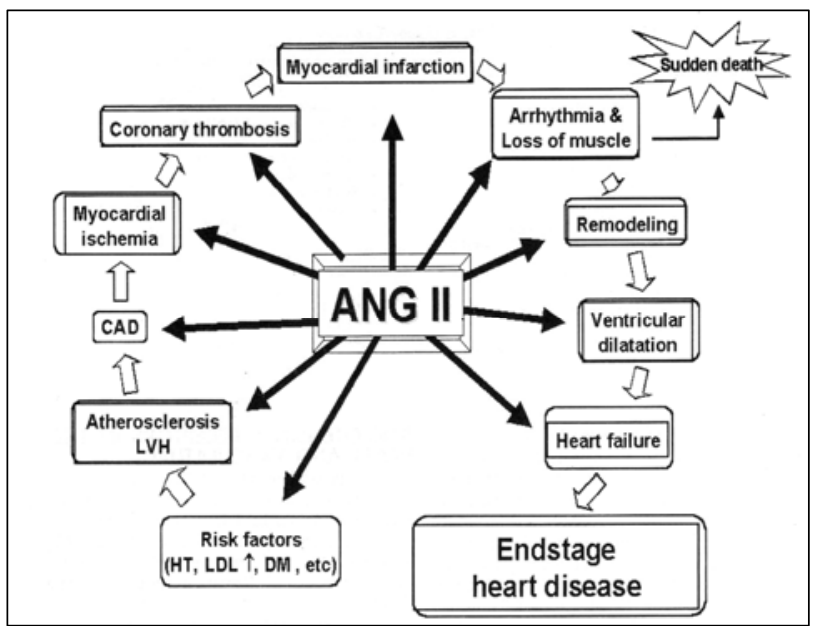

Figure (3): The cardiovascular continuum. Reproduced with permission from Prof. $\mathrm{T}$. Unger, the role of the renin-angiotensin system in the development of cardiovascular disease. AMJ card. ${ }^{(31)}$.

Central to all these pathways is the activation of the renin - angiotensin system with angiotensin II binding to $\mathrm{AT}_{1}$ receptor as a major effector, producing acute vasoconstriction, leading to an increase in blood pressure and independently to chronic disease pathology by promoting vascular growth and proliferation, and endothelial dysfunction, i.e., atherosclerosis (25). Experimental evidence clearly suggests a key role of the RAS and the induced inflammatory processes at all stages of this continuum and consequently a strong rational for its blockade in order to prevent cardiovascular events. Inhibition of the system has a potent anti atherosclerotic effect which is mediated by their antihypertensive, anti-inflammatory, antiproliferative, and oxidative stress lowering properties. The possibility of a positive effect of the RAS blockade at the early stages of cardiovascular continuum, that is, the endothelial dysfunction was specifically addressed by some clinical studies ${ }^{(26)}$.

\section{Inhibition of the RAS}

Because angiotensin II has a pivotal role in the sequence of events constituting the cardiovascular continuum, and the implication of chronic RAS activation as a major factor contributing to progressive dysfunction of target organs, it would seems logical to target the RAS in therapeutic strategies aimed at reducing the overall cardiovascular risk-factor profile of an individual. Identification of this link between angiotensin $\|$ and the pathophysiologic changes associated with various cardiovascular conditions prompted the development of pharmaceutical agents, capable of blocking the actions of angiotensin II and reducing the associated pathologies. Firstly, the ACE inhibitors were available, and more recently, the selective $A T_{1}$ receptor antagonists.

Proven cardiovascular benefit from angiotesin-converting enzyme (ACE) inhibitions is a cornerstone of evidence-based medicine ${ }^{(27)}$. The first study to show dramatic benefits from ACE inhibition was the Cooperative North Scandinavian Enalpril Survival Study (CONSENSUS-1), in which a $31 \%$ decrease in the rate of death was observed in patients with severe heart failure at the end of 1 year of enalpril treatment ${ }^{(28)}$. (figure 4). 


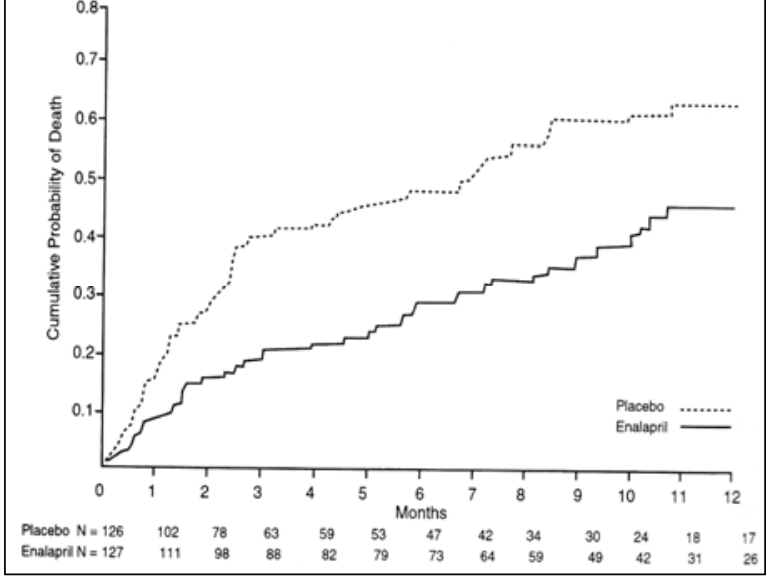

Figure (4): Kaplan-Meier curve from the Cooperative North Scandinavian Enalapril Survival Study (CONSENSUS-1). Reproduced with permission from Prof. T. Unger, the role of the renin-angiotensin system in the development of cardiovascular disease. AMJ card. ${ }^{(31)}$.

Other studies SAVE \& AIRE ${ }^{(29)}$ verified that ACE inhibition decrease heart failure, myocardial infarction, and mortality, and that striking benefit could be observed within 30 days. The Heart Outcomes Prevention Evaluation (HOPE) study conclusively demonstrated that ramipril angiotesinconverting enzyme (ACE) inhibitor reduces the risk of a primary cardiovascular event (death, stroke, or acute $\mathrm{M} \mathrm{I}$ ) in high-risk patients by $22 \%{ }^{(30)}$. (figure 5 )

Theoretically, $\mathrm{AT}_{1}$ receptor antagonists might offer even greater improvements in clinical outcomes than ACE inhibitors because they selectively block the negative actions of angiotensin II that are mediated through $\mathrm{AT}_{1}$ receptors yet preserve (and potentially amplify) the favorable effects mediated by through $\mathrm{AT}_{2}$ receptors ${ }^{(31)}$. A growing body of data indicates that ARBs can improve cardiovascular outcomes in patients with hypertension as well as in patients with related conditions such as heart failure ${ }^{(31,32)}$. Accordingly it has been used in patient intolerant to ACE inhibitor with equal efficacy and of course with fewer side effect (cough and angioedema).

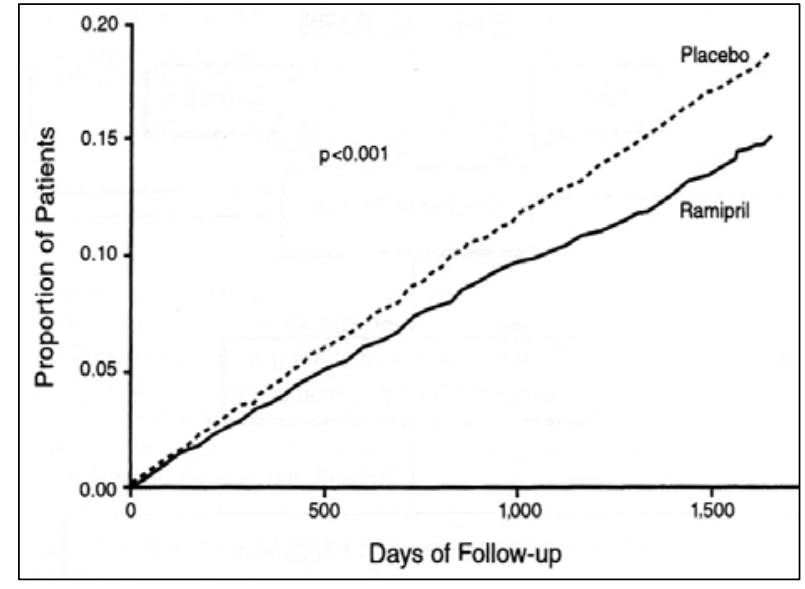

Figure (5): Kaplan-Meier estimates of the primary composite outcome of my myocardial infarction, stroke or death from cardiovascular causes from the Hypertension Outcomes Prevention Evaluation (HOPE) study. Reproduced with permission from Prof. $T$. Unger, The Role of thr renin-angiotensin system in the development of cardiovascular disease. AMJ card. ${ }^{(31)}$.

In theory also, more complete RAS blocked using a combination of an ACE inhibitor and an $\mathrm{AT}_{1}$ receptor antagonist should provide even greater attenuation of the deleterious angiotensin II-induced local tissue effects ${ }^{(31)}$, because it produces more complete blockade of the RAS, while preserving the beneficial effects mediated by $\mathrm{AT}_{2}$ receptor stimulation and increased bradykinin levels which possesses vasodilatory and tissue - protective properties. (table 3). The randomized evaluation of strategies for left ventricular dysfunction (RESOLVD) study indicated that combining an ACE inhibitor with an ARB decreases blood pressure and improved the ejection fraction more than treatment with either drug alone in patient with heart failure ${ }^{(34)}$, and the valsartan in heart failure trial (ValHeft) showed that the combination of an ACE inhibitor and an ARB reduces hospitalization for heart failure in patients with CCF by $27.5 \%$ (35). 
Table (3): The Potential Overall Effects of ACE inhibitors and ARBs Combination.

\begin{tabular}{|l|l|l|l|}
\hline & \multicolumn{1}{|c|}{ ACE Inhibitor } & \multicolumn{1}{|c|}{$\begin{array}{c}\mathrm{AT}_{1} \text { Receptor } \\
\text { Antagonist }\end{array}$} & $\begin{array}{c}\text { ACE Inhibitor }+\mathrm{AT}_{1} \\
\text { Receptor Antagonist }\end{array}$ \\
\hline \hline $\mathrm{AT}_{1}$ stimulation & $\downarrow$ & $\downarrow \downarrow$ & $\downarrow \downarrow$ \\
\hline $\mathrm{AT}_{2}$ stimulation & $\downarrow$ & $\uparrow \uparrow$ & $\uparrow$ \\
\hline Plasma rennin activity & $\uparrow$ & $\uparrow$ & $\uparrow$ \\
\hline Angiotensin II levels & $\downarrow$ & $\uparrow$ & $=/ \uparrow$ \\
\hline Bradykinin levels & $\uparrow$ & $=$ & $\uparrow$ \\
\hline
\end{tabular}

Reproduced with permission from Prof. T. Unger, the role of the renin-angiotensin system in the development of cardiovascular disease. AMJ card. ${ }^{(31)}$.

But, unfortunately, these theoretical expectations could not be confirmed by the most recently published clinical trials. In TRANSCEND study ${ }^{(36)}$ which compared (telmisartan) an ARB to placebo, the result have shown that the active treatment (telmisartan) was not superior to placebo in the prevention of cardiovascular events, primary composed end point represented by cardiovascular death $\mathrm{Ml}$, stroke, or admission to the hospital for heart failure events. The ONTARGET trial (published recently, a very large multicenter randomized trial) in which the patients were treated with an ACE inhibitor (ramipril), an ARB (telmisartan), or the combination of the two drugs ${ }^{(37)}$. After a medium follow up of 56 months the occurrence of the primary outcomes, consisting of death from cardiovascular causes, MI, stroke, or hospitalization for heart failure, was not significantly different in the ramipril and telmisartan groups, though the ARB was better tolerated. However, there were trends slightly favoring the ACE inhibitor for MI prevention and the ARB for stroke prevention, but these differences did not reach statistical significance. The other important issue addressed by the trial, the clinical role of the combined renin-angiotensin blockade, brought a word of caution about this strategy since more adverse events were observed. Ripley \& Harison suggested that these unexpected data could be explained by the differences in patients number, event rate and the use of other life saving drugs between these studies and HOPE studies ${ }^{(38)}$. However, these results confirmed the difficulty to the demonstrate a significant effect of the renin-angiostensin blockade in the cardiovascular prevention beyond the blood pressure control.

In addition, Skeggs et al., suggested another possible approach to inhibit the RAS which is renin inhibition ${ }^{(39)}$. Renin inhibitors are under investigation and phase III trials have shown their effectiveness at lowering blood pressure $(40,41)$. Compared with the ACE inhibitors, renin inhibitors have few side effects and may be indicated in combination of drugs such as diuretics, ACE inhibitors, and ARBs which increase plasma renin through feed-back loops. They are illuminated via the liver with little interaction with other drugs and may be useful in patient with concomitant renal disease ${ }^{(42)}$. Of course, renin inhibitors offer the potential to inhibit the entire cascade of the system. Although the results from AGELESS study showed the first - in - class direct renininhibitor aliskiren provides significantly greater blood pressure reduction compared to ACE inhibitor ramipril ${ }^{(43)}$, but at present, the effects independent of antihaypertensive activity of aliskiren have been shown by one clinical trial focused on end - organ damage. In aliskiren in the evaluation of proteinuria in diabetes (AVOID) trial, the treatment with aliskiren reduced proteinuria independently of blood pressure ${ }^{(44)}$. Other clinical trials have been started to investigate the possible benefit of aliskiren in cardiac remodeling after myocardial infarction (AVANT GARDEASPIRE) and diabetic nephropathy (ALTITUTE) ${ }^{(45)}$. Therefore, in the next future, further clinical evidence will be available to confirm these preliminary anti-inflammatory and anti-atherosclerotic effects of renininhibitors in humans. 


\section{RAS and hypertensive disease}

Patients with hypertension die prematurely, the most common cause of death is heart disease, followed by stroke and renal failure. The excess morbidity and mortality related to hypertension are progressive over the whole range of systolic and diastolic blood pressures, the risk approximately doubles for each 6 $\mathrm{mmHg}$ increased in diastolic blood pressure (46). Cardiac complications are the major causes of morbidity and mortality due to target - organ damage caused by hypertension and prevention of this damage should be a major goal of therapy. The most important cardiovascular target-organ damage caused by hypertension are: left ventricular hypertrophy, atrial fibrillation and stroke.

\section{Left ventricular hypertrophy}

It is one of the early organ damage caused by hypertension which by itself increases the risk of major cardiovascular event 2-5 folds ${ }^{(47)}$. Angiotensin II, acting through the $\mathrm{AT}_{1}$ receptor, is involved in virtually every step along the cardiovascular continuum. Consequently, any intervention that specifically blocks these actions can be expected to have a significant impact on cardiovascular morbidity and mortality by retarding the succession of events (figure 4). Evidences for an association between the RAS and L. V. H. stem from:

1. Left ventricular hypertrophy has been shown to be high in patient with renal artery stenosis, a stage characterized by the system activation compared with patients with primary hypertension at similar levels of blood pressure ${ }^{(48)}$.

2. In a study cohort of untreated hypertensive people (49) high "angiotensin II concentrations were closely associated with high left ventricular mass (figure 6) subsequent analysis revealed that increased activity and insufficient suppression of the RAS corresponds to inadequately high left ventricular mass in relation to the $24 \mathrm{hr}$ ambulatory blood pressure load $^{(50,51)}$.

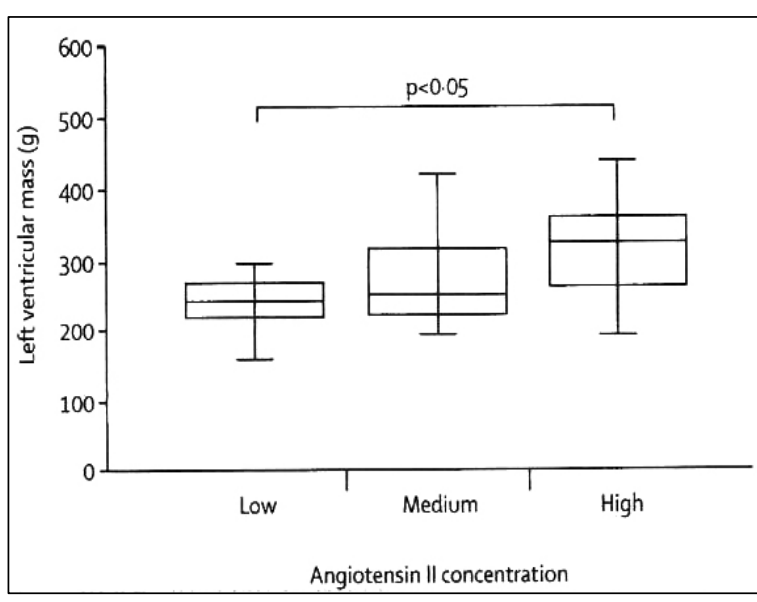

Figure (6): Box plot of left ventricular mass in never treated patients, according to angiotensin 11 concentrations in relation to urinary sodium excretion. Reproduced with permission from Prof. R. F. Schmieder. Renin - angiotensin system and cardiovascular risk. Lancet $2007^{(65)}$

3. Further evidence of an association between RAS and LVH stem from therapeutic trials of the five antihypertensive agents recommended as first - line treatment, calcium antagonists, ACE inhibitors, and ARBs reduce left ventricular mass to a greater extent than do B-blockers and diuretics (figure 7$)^{(52,}$ 53)

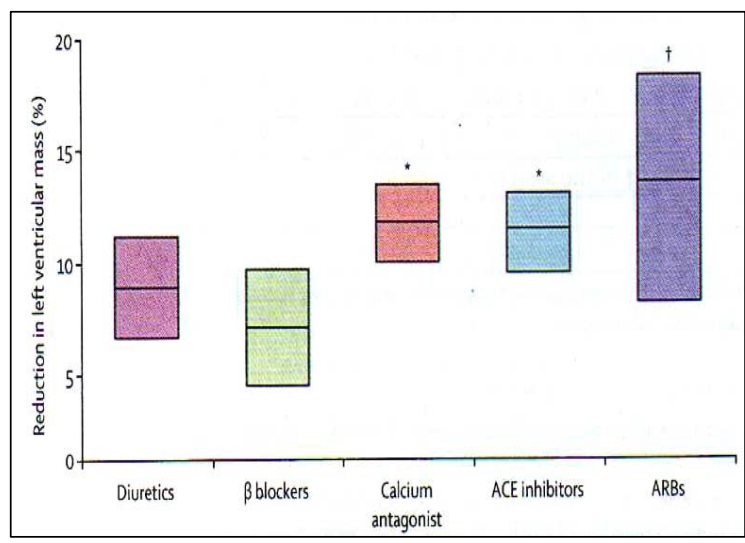

Figure (7): Reduction of left ventricular mass stratified according to various antihypertensive regimens. Reproduced with permission from Prof. R. F. Schmieder. Renin - angiotensin system and cardiovascular risk. Lancet 2007 (65) 
In addition, in a prospective trial "LIFE study" ${ }^{(54)}$ with hypertensive patients who had L.V.H. at baseline the investigators consistently reported that reduction of L.V.H. was greater with the ARB Losartan than with the $\beta$-blocker atenelol, and this effect was maintained at similar blood pressure levels throughout the whole follow-up of 5 years ${ }^{(55)}$. Thus, it is not only a question of treatment duration or achieved blood pressure, but the choice of drug is also of clinical relevance to the treatment of L.V.H. In addition many clinical trials ${ }^{(56)}$ have clearly shown that reduction of L.V.H. translates in to a reduced rate of cardiovascular complications and improved prognosis. Accordingly, reduction of L.V.H. appears as a therapeutic goal in primary hypertension that should be taken seriously.

\section{Atrial fibrillation}

Atrial fibrillation is the most common sustained cardiac arrhythmia, affecting roughly $1 \%$ of people younger than 65 years. The incidence and prevalence of atrial fibrillation steeply rises with advancing age affecting $5 \%$ of individuals older than 65 years ${ }^{(57)}$ and $9 \%$ of those aged over 80 years of note, $70 \%$ of atrial fibrillation patients are aged between 65 and 85 years, and overall $84 \%$ are older than 65 years ${ }^{(58)}$. Atrial fibrillation increases the risk of cardiovascular mortality by two-fold and it is the cause of up to $15 \%$ of all strokes ${ }^{(59,60)}$.

Hypertension is the most important risk factor for atrial fibrillation on a population basis, and in hypertensive patients, age, left atrial chamber diameter, and left ventricular mass have been identified as independent risk features for the development of atrial fibrillation (61)

The rule of renin-angiotensin system in the pathogenic mechanism of atrial fibrillation stemmed from many therapeutic trials. In hypertensive patients with atrial fibrillation at baseline, the LIFE study findings suggested that treatment based on ARBs was more effective than that based on B-blockers in reducing the risk of the composite cardiovascular endpoint, stroke and death ${ }^{(62)}$. Similarly, treatment with ARBs reduced the frequency of atrial fibrillation in patients without atrial fibrillation at baseline by $21 \%{ }^{(63)}$, and in
VALUE study, new atrial fibrillation onset was less frequent in those on ARBs than in those on calcium antagonists ${ }^{(64)}$. Accordingly, reninangiotensin system blockade has emerged as a new preventive and therapeutic strategy for atrial fibrillation ${ }^{(65)}$.

\section{Stroke}

Stroke is the third most common cause of death in the developed world after cancer and ischemic heart disease, and is the most common cause of severe physical disability (66). About one-fifth of patients with an acute stroke will die within a month of the event, and at least half of those who survive will be left with physical disability ${ }^{(66)}$. The incidence and prevalence of stroke increases linearly with age and blood pressure ${ }^{(67)}$, accordingly the most crucial factor in stroke prevention is best possible blood pressure control ${ }^{(68)}$.

Meta-analysis suggest that ARBs (but not ACE inhibitors) are effective in stroke prevention beyond blood pressure control ${ }^{(68)}$. The explanation of this result came from animal studies ${ }^{(69)}$, treatment with ARBs improved neurological outcome of focal central ischemia and protected brain tissue against ischemic injury. Stimulation of the $\mathrm{AT}_{2}$ receptor induces vasodilatation because it potentiates locally synthesized nitric oxide and prostacycline, which in turn could improve cerebral blood flow by collateral circulation ${ }^{(70)}$. In the brain region adjacent to the infarct area, $A T_{1}$ receptor density remained unaltered but $A T_{2}$-receptors were upregulated in neurons ${ }^{(70}$, 71) and selective blockade of central $A T_{2}$ abolished the neuroprotective effect of ARBs (70). Thus experiments have shown that cerebral $\mathrm{AT}_{2}$ receptors exert neuroprotective effects in response to ischemia induced neuronal injury ${ }^{(70)}$.

These new experimental findings helped to explain the results of several clinical trials. In a trial of hypertensive patients aged 35-64 years, diuretics that activate the RAS prevented substantially more stroke than did $\beta$-blockers, which suppress the system activity by equal blood pressure reductions ${ }^{(72)}$. In hypertensive patients with stroke, the PPARS study (73) showed that the ACE inhibitor resulted in $5 \%$ stroke reduction, compared with 
a $43 \%$ stroke reduction if the diuretic indapamide was added. In hypertensive patients with LVH but without previous stroke, the LIFE study showed a $25 \%$ reduction in strokes with ARB based regimen that the $\beta$ blocker one ${ }^{(41)}$ similar results were reported in patients with isolated systolic hypertensive ( $40 \%$ \& $24 \%$ stroke reduction) in LIFE study and SCOPE respectively ${ }^{(74,75)}$. In these trials with ARBs, control of blood pressure was much the same, suggesting that the recorded difference in stroke frequency could be attributed specifically to treatment with ARBs. Finally in a meta-analysis, calcium antagonists that do not affects the RAS reduced the risk of stroke better than did ACE inhibitors ${ }^{(58)}$.

In summary, the most important factor in stroke prevention is good blood pressure control, and the control of systolic blood pressure might be of particular importance ${ }^{(76)}$ and the cerebroprotective effects of the $A T_{2}$ receptor stimulation by ARBs (77) have emerged as an important clinical means to reduce the serious target-organ damage of hypertension namely the ischemic stroke.

\section{Conclusion}

The renin-angiotensin system (RAS) is a major contributor to both hypertension and associated pathophysiologic changes in the heart and vascular wall (the target organ). Major clinical trials have shown that angiotensin converting enzyme and angiotensin receptor blockers assist in controlling hypertension and reducing target organ damage.

To advance clinically, it is important to optimize treatment directed at the RAS, i.e., more complete RAS blockade using a combination of an ACE inhibitors and RABs to maximize patients benefit. Theoretically, it seems logical but, results of the recent clinical trials did not confirm this expectation and appear to be associated with little more adverse effect. Renin inhibitors are other advances because they offer the potential of inhibiting the entire cascade of the system. Clinical trials have been started to investigate this possibility and the results are awaited in the near future.

\section{References}

1. Khalil ME, Basher AW, Brown FT, Alhadad IA: A remarkable medical story: benefits of angiotensin - converting enzyme inhibitors in cardiac patients. J Am Coll cardiol 2000;37:1757-1764.

2. Johnston $\mathrm{Cl}$, Risvanis J., Preclinical Pharmacology of angiotensin II receptor antagonists: update and outstanding issues. Am. J. Hypertens 1997; 10, 306S310 S.

3. Chung $O$, Stoll $M$, Unger T. Physiologic and pharmacologic implications of $\mathrm{AT}_{1}$ versus $\mathrm{AT}_{2}$ receptors. Blood Press 1996, 5, Suppl 21: 47-52.

4. deGasparo M, Catt KJ, Inagami T, Wright $\mathrm{JW}$, Unger $\mathrm{T}$. International Union of Pharmacology XXIII. The angiotensin II receptors. Pharmacol Rev 2000; 52: 415472.

5. Timmerman PB, Wong PC, Chiu AT, Herblin WF, Benfield P, Carini DJ, Lee RJ, Weker RR, Saye JA, Smith RD: Angiotensin II receptors and angiotensin II receptor antagonists. Pharmacol Rev. 1993; 45: 205-251.

6. Geisterfer AA, Peach MJ, Owens GK. Angiotensin II induces hypertrophy, not hyperplasia, of culture rat aortic smooth muscle cells. Circ. Res. 1988; 62: 749751.

7. Paquet JC, Baudouim- legros M, Brunelle $G$, Meyer P. Angiotensin II induced proliferation of aortic myocytes in spontaneous hypertensive rats. J. Hypertens 1990; 8: 565-572.

8. Stoll M, Steckelings UM, Paul M, Bottari SP, Metzger R, Unger T. The Angiotensin $A T_{2}$ receptor mediators inhibition of cell proliferation in coronary endothelial cells. $\mathrm{J}$ Clin Invest 1995; 95: 651-657.

9. Lucius R, Gallinat S, Busche S, Rosensteil $\mathrm{P}$, Unger $\mathrm{T}$. Beyond blood pressure: new roles for Angiotensin II. Cell Mol life Sc. 1999; 56; 1008-1009.

10. Unger T, Chung $O$, Csikos T, Culman J, Gallinai S, Gohike P, Hohles S, Meffert S, Stoll M, Stroth U, Zhu YZ. Angiotensin receptors. J Hypertens 1996; 14 (Suppl 5): 595-103. 
11. Unger T, Culman J, Gohike P. Angiotensin II receptor blockade and endorgan protection: pharmacological rational and evidence. J Hypertens 1998; 16, (Suppl 7) 53-59.

12. Lucius R, Gallinai $S$, Rosentiel $P$, Herdegen $\mathrm{T}$, Siever J, Unger $\mathrm{T}$. The Angiotensin II type 2 (AT $)$ receptor promote axonal regeneration in the optic nerve of adult rats. J Exp, Med 1988; 188: 661-670.

13. Nio $\mathrm{Y}$, Matsubara $\mathrm{H}$, Murasawa $\mathrm{S}$, Kanasaki M, Inada M. Regulation of gene transcription of Angiotensin II receptor subtypes in myocardial infarction. J Clin Inves 1995; 95: 46-54.

14. Kimura B, Sumners C, Phillips MI. Changes in skin Angiotensin II receptors in rats during wound healing. Biochem. Biophys Res Commun 1992; 187: 10831090.

15. Nakajima M, Hutchinson HG, Fujinaga $M$, Hayashida W, Morishita R, Zhang L, Horiuchi M, Partt RF, Dzau VJ. The Angiotensin II type $2\left(\mathrm{AT}_{2}\right)$ receptor antagonizes the growth effects of the $A T_{1}$ receptor: gain-of-function study using gene transfer proc Nat Acad Sci USA 1995; 92 : 1063-1067.

16. Donoghue M., Hsich F., Baranas E., et al. A novel angiotensin -converting enzymerelated carboxy peptidase (ACE2) convert angiotensin 1 to angiotensin 1-9. Circ Res 2000; 87: E1-9.

17. Ferrario CM. Angiotensin - converting enzyme 2 and angiotensin (1-7), an evolving story in cardiovascular regulation. Hypertension 2006; 47: 515-21.

18. Crackower MA, Sarao R, Oudit GY, et al. angiotensin - converting enzyme 2 is an essential regulator of heart function. Nature 2002; 417: 822-28.

19. Li W, Moore MJ, Vasilieva N, et al. Angiotensin - converting enzyme 2 is a functional receptor for the SARS coronavirus. Nature 2003; 426: 450-04.

20. Chai SY, Fernando R, Peck G, et al. The angiotensin $\mathrm{IV} / \mathrm{AT}_{4}$ receptor. Cell mol life SC. 2004 ; 61 : 2728-37.
21. Nguyen G, Delarve F, Burkle C, Bouzhir I, Giller T, Svaer JD. Pivotal role of the renin/ prorenin receptor in angiotensin II production and cellular responses to rennin. J Clin Invest 2002; 109: 1417-27.

22. Burckle CA, Jan Danser AH, Muller DN, et al. Elevated blood pressure and heart rate in human rennin receptor transgenic rats. Hypertension 2006; 47: 552-56.

23. Danser AH, Deinum J. Renin, prorenin and the putative (pro) renin receptor. Hypertension 2005; 46: 1069-76.

24. Dzau V, Braunwald E. Resolved and unresolved issues in the prevention and treatment of coronary artery disease: a workshop consensus statement. Am Heart J. 1991; 121: 1244-1263.

25. Brunner HR, Gavras H. Angiotensin blockade for hypertension: a promise fulfilled. Lancet 2002; 359: 988-992.

26. Montecucco F, Pende A and Mach F: The Renin - Angiotensin modulates inflammatory processes in Atherosclerosis: Evidence from basic research and clinical studies. Mediators of inflammation 2009;209:1155-1170.

27. Sleight $P$. Angiotensin 11 and trials of cardiovascular outcomes. AMJ card 2002; 89: $11 \mathrm{~A}-16 \mathrm{~A}$.

28. The CONSENSUS Trial study group. Effects of enalpril on mortality in severe congestive heart failure. Results of the Cooperative North Scandinavian Enalpril Survival Study (CONSENSUS). N Engl. J. Med 1987; 316: 1424-1435.

29. The Acute Infarction Ramipril Efficacy (AIRE) Study Investigation. Effects of ramipril on mortality and morbidity of survivors of acute myocardial infraction with clinical evidence of heart failure. Lancet 1993; 342: 821-828.

30. The Heart Outcomes Prevention Evaluation Study Investigators (HOPE). Effect of an angiotensin - converting enzyme inhibitor, ramipril, on cardiovascular events in high-risk patients. N Engl J Med 2000; 342: 145-153.

31. Unger $\mathrm{T}$. The role of the renin- angiotensin system in the development of 
cardiovascular disease. A symposium, AMJ card. 2002 89: 3A-9A.

32. Young JB et al; Candesartan in heart failure. Assessment of reduction in mortality and morbidity (CHARM) Investigator \& committees. Circulation 2004; 110; 2618.

33. Bashore TM, Granger CB and Hranitzky P. Congestive heart failure. In CMDT 2007; 394-406.

34. Mckelvie RS, Yusuf S, Pericak D, Averum A, Burus RT, Probstfield T, Tsuyuli RT et al, Comparison of candesartan, enalpril, and their combination in congestive heart failure randomized evaluation of strategies for left ventricular dysfunction (RESOLVD) pilot study. Circulation 1999; 100: 10561064.

35. Cohn JN and Taqnoni G. For the valsartan heart failure trial investigator. A randomized trial of the angiotensin receptor blocker valsartan in chronic heart failure. N Engl J Med 2001; 345: 16671675.

36. Yusuf S., Teo K.K., Pogue J., et al., Telmisortan, ramipril or both in patients at high risk for vascular events "The N Eng. J of Med., 2008; 358: 1547-1559.

37. Manu J.F., Schmieder R.E., McQueen M., et al., Renal outcome with telmisartan, ramipril or both, in people at high vascular risk (the ONTARGET study), a multi center, randomized, double blind, controlled trial, "The lancet 2008; 372: 547-553.

38. Ripley T.L. and Harrison, "The power to Transcend", The Lancet 2008; 372: 11281130.

39. Skeggs L.T., Kahn J.R., Lentz K., and Shumulay N. P. The preparation, Purification and amino acid sequence of a polypeptide renin substrate. "The $\mathrm{J}$. of Exp. Med., 1957;106: 439-453.

40. Aziz M, Webb R, Nussberger J, Hollenberg NK: Renin inhibition with aliskiren: where are we now, and where are we going? J Hypertension 2006; 24: 243-56.

41. Gradman $A H$, Schmieder RE, Lins RI, Nussberger J, Chiang $\mathrm{Y}$, Bedigian MP.
Aliskiren, a novel orally effective rennin inhibitor, provides dose-dependent antihypertension efficacy and placebo- like tolerability in hypertensive patients. Circulation 2005; 111: 1012-18.

42. Kelly JS. Aliskiren, an orally active renin inhibitor. JR Coll Physician Edin 2007; 37: 125-127.

43. Duprez DA et al. The AGELESS study: The effect of Aliskiren vs Ramipril alone or in combination with hydrochlor thiazide and Amlodipine in patients $>65$ years of age with systolic hypertension. Oral presentation at the American Heart Association 2008 Scientific Sussions.

44. Parvine H.H., Persson F., Lewis J.B. and Hollenberg N.K.: Aliskiren combined with Losartan in type 2 diabetes and nephropathy. The New Eng J. of Med., 2008;358: 2433-2446.

45. Westermann D., Schmieder R., Schultheiss H.P., and Tschope C. "Renin inhibitors, clinical experience", J. of Molecular Med., 2008;86: 691-995.

46. Suttars M. Systemic hypertension: In CMDT 2007; 46 ed., 429-459.

47. Lory D, Corrison RJ, Savagl DD, Kannel NB, Castell WP. Prognostic implications of echocardiographically determined left ventricular mass in the Framingham Heart Study. N Engl. J. Med. 1990; 322: 15611566.

48. Rizzoni D, Muiesan ML, Porten EN, et al. Relations between cardiac and vascular structure in patient with primary \& secondary hypertension. J Am Coll Cardiol 1998; 32: 985-992.

49. Schmieder RE, Langerfeld MR, Friedrich A, Schobel HP, Gatzka CD, Weihprech $\mathrm{CH}$. Angiotensin II related to sodium excretion modulars left ventricular structure in human essential hypertension circulation 1996; 94: 1304-1309.

50. Klingbeil AU, Schobel H, Langenfeld MR, Hilgers K, Schaufelc T, Schmieder RE. Hyper-responsiveness to angiotensin II is related to cardiac structural adaptation in hypertension subject. J Hypertens 1999; 17: 825-833. 
51. Schlaich MP, Shobel HP, Langenfeld MR, Hilgers K, Schmieder RE. Inadequate suppression of angiotensin II modulate L.V. structure in human. Clin Nephrol 1998; 49: 157-159.

52. Galzerano D, Tammaro $P$, delViscovo $L$, et al. Three-dimensional echo and magnetic resonance assessment of the effect of telmisartan compared with carvedilol on L.V. mass a multicenter, randomized longitudinal study. Am J Hypertens 2005; 18: 1563-1569.

53. Klingbeil AU, Schmieder $M$, Marhus $P$, Messekli FH, Schicder RE. A metaanalysis of the effects of treatment on left ventricular mass in essential hypertension. Am J. Med 2003; 115: 41-46.

54. Dahlof B, Devereux RB, Kjeldsen SF, et al. Cardiovascular morbidity and mortality in the losartan intervention for endpoint reduction in hypertension study (LIFE) a randomized trial against atenolol. Lancet 2002; 359: 995-1003.

55. Devereux RB, Dahlof B, Gredts E, et al. progression of hypertension L.V.H. by losartan compared with atenolol. The losartan intervention for endpoint reduction in hypertension (LIFE) trial. Circulation 2004; 110: 1456-1462.

56. Verdecchia $P$, Angeli $F$, Borgioni $C$. et al. Changes in cardiovascular risk by reduction of left ventricular mass in hypertension: a meta-analysis. Am J hypertens 2003; 16: 895-899.

57. Kannel WB, Wolf PA, Benjamin ET, Levy $D$. Prevalence, incidence, prognosis, and predisposing conditions for atrial fibrillation: population - based estimation. Am J Cardiol; 1998; 82: 2N-9N.

58. Bloomfield P, Bradbury A, Gubb NR, Newby DE. Atrial fibrillation in Davidsons principles and practice of medicine 20th ed, 2006; 562-564.

59. Lip GYH, Lahukota K. Atrial fibrillation JR Coll Physician Edin. 2007; 37: 238-243.

60. Wattingney WA, Mensah GA, Croft JB, Increasing trends in hospitalization for atrial fibrillation in the United States. 1985 through 1994: implication for primary prevention. Circulation 2003; 108: 711716.

61. Verdechia P, Reboldi G, Gattobigio R, et al. Atrial fibrillation in hypertension: predictors and outcome. Hypertension 2003; 41: 218-223.

62. Wachtell K, Horrestam B, Lehto M, et al. Cardiovascular morbidity and mortality in hypertensive patients with history of AF. The losartan intervention for end point reduction in hypertension (LIFE) study. J Am Coll Cardiol. 2005; 45: 705-711.

63. Wachtell K, Lehto M, Gerdts E, et al. Angiotensin II receptor blockade reduces new-onset atrial fibrillation and subsequent stroke compared to atenolol: the losortan intervention for end point reduction in hypertension (LIFE) study. J Am Coll Cardiol. 2005; 45: 712-719.

64. Schmieder R, Kjeldsan $S$, Julius $S$, Melnnes GT, Zanchetti A, Hua T. Reduced incidence of new onset atrial fibrillation with Angiotensin II receptor blockade: The value-trial. J hypertens 2006; 24: (suppl.): 53.

65. Schmieder RF, Hilger KF, Schlaich MP, Schmidt BMW. Renin- Angiotensin system and cardiovascular risk. Lancet 2007, 369: 1208-1219.

66. Allen CMC, Lueck CJ and Dennis M. Cerebrovascular disease in Davidson's principles and practice of medicine. 20th edition 2006, 1200-1210.

67. Lewington S, Clarke R, Qizilbash N, Peto $\mathrm{R}$, Collins R. Age-specific relevance of usual blood pressure to vascular mortality; a meta-analysis of individual data for one million adults in 61 prospective study. Lancet 2002; 360: 1903-1913.

68. Turnbuil F. Effect of different bloodpressure-lowering regimens on major cardiovascular events: results of prospectively - designed overviews of randomized trials. Lancet 2003; 362: 1527-1535.

69. Groth W, Blume A, Gohlke P, Unger T, Culman J. Chronic pretreatment with candesartan improves recovery from focal cerebral ischemic in rats. J Hypertens 2003; 21: 2175-2182. 
70. Li J, Culman J, Hortnagl $\mathrm{H}$, et al. Angiotensin $\mathrm{AT}_{2}$ receptor protects against cerebral ischemia-induced neuronal injury. Faseb J 2005; 19: 617-619.

71. Sigmund CD, Davisson RL. Targeting brain $\mathrm{AT}_{1}$ receptors by RNA interference. Hypertension 2006; 47: 145-146.

72. Medical Research Council Working Party. MRC trial of treatment of mild hypertension: principal results, $\mathrm{Br}$. Med. J. (Clin Res Ed.) 1985; 291: 97-104.

73. Progress collaborative group. Randomized trial of a prindopril - based blood pressure lowering regime among 6105 individuals with previous stroke or TIA. Lancet 2001; 385: 1033-1041.

74. Kjeldsen SE, Dahlof B, Devereux RB, et al. Effects of losartan on cardiovascular morbidity and mortality in patient with isolated systolic hypertension and LVH: a Losartan intervention for endpoint reduction (LIFE) substudy. JAMA 2002; 288: 1491-1498.
75. Lithell H, Hansson L, Skoog I, et al. The study on cognition and prognosis in the elderly (SCOPE): principal results of a randomized double - blind intervention trial. J Hypertens 2003; 21: 875-886.

76. Williams B, Lacy PS, Thom SM, et al. Differential impact of blood pressure lowering drugs on central aortic pressure and clinical outcomes: principal results of the Conduit Artery Function Evaluation (CAFE) study. Circulation 2006; 113: 1213-1225.

77. Hosomi N, Nishiyama A, Ban CR, et al. Angiotensin type I receptor blockade improves ischemic injury following transient focal cerebral ischemia. Neuroscience 2005; 134: 225-231. 